\title{
Ventilation and oxygen uptake by three species of Nereis (Annelida : Polychaeta). II. Effects of temperature and salinity changes
}

\author{
Erik Kristensen
}

Institute of Ecology and Genetics, and Department of Zoophysiology, University of Aarhus, DK-8000 Aarhus C, Denmark

\begin{abstract}
Ventilation and oxygen uptake of Nereis virens, $N$. succinea and $N$. diversicolor were monitored during changing temperatures $\left(5.5\right.$ to $\left.37.5^{\circ} \mathrm{C}\right)$ and salinities $(1.7$ to $24.0 \% \mathrm{~S})$. Measurements were performed using a direct flow sensing technique with worms in polyethylene tubes simulating natural conditions. Ventilation amplitude increased with temperature $\left(Q_{10}=2.6\right.$ to 2.9$)$ for the 3 species, reaching well defined species specific upper limits. This is assumed to be the upper limit for Nereis ventilation capacity. At temperatures above 30 to $35^{\circ} \mathrm{C}$, but below the lethal limit, ventilation decreased and eventually ceased. Oxygen uptake during active periods appeared to increase with temperature over the range measured $\left(Q_{10}=1.3\right.$ to 2.2$)$. Ventilation requirement $\left(\dot{V}_{\mathrm{O}_{2}} \sim \dot{V}_{w}\right)$ showed minimum values at species specific temperatures, suggesting optimum temperatures at the present acclimation level ( $N$. virens, 11 to $20^{\circ} \mathrm{C} ; N$. succinea 20 to $35^{\circ} \mathrm{C}$ and, $N$. diversicolor, 5 to $16^{\circ} \mathrm{C}$ ). Reduction in salinity resulted in a decreased ventilation amplitude, possibly due to osmotic swelling of the worms. Oxygen uptake during active periods was quite unaffected by salinity changes. Ventilation requirement increased for all 3 species at low salinities and was most pronounced in the stenohaline $N$. virens and least in the euryhaline $N$. diversicolor. The observed responses to temperature and salinity changes are also related to distributional patterns of the 3 species in a Danish estuary
\end{abstract}

\section{INTRODUCTION}

Annelid polychaetes of the genus Nereis are among the most common and abundant members of the Danish estuarine infauna. Nereis virens Sars, N. succinea (Frey \& Leuckart) and N. diversicolor O. F. Müller each occupy distinct areas of estuaries (Muus, 1967; Rasmussen, 1973). These distributional patterns are thought to result from differences in tolerance limits to extreme and variable environmental conditions as well as from interspecific competition (Rasmussen, 1973; Kristensen, 1981a).

While there is a multitude of factors which can affect activity level and oxygen consumption of an animal, 2 of the most important environmental factors are temperature and salinity. Synergistic interactions between these factors can be expected to regulate the distribution and activity of many estuarine invertebrates. Within estuaries temperature and salinity conditions vary tidally and diurnally. The effects of each of these individual factors on simultaneously measured ventilation and oxygen uptake has been well documented for marine bivalves (McLusky, 1973; Widdows, 1973; Newell and Kofoed, 1977; for review see Remane and
Schlieper, 1971; Newell and Branch, 1980) and crustaceans (Halcrow and Boyd, 1967; Taylor, 1977; Taylor et al., 1977; Dyer and Uglow, 1980; for review see Kinne, 1970, 1971; Remane and Schlieper, 1971), but attempts to study this on polychaetes are scarce (Mangum and Sassaman, 1969). Comparative measurements of ventilation and oxygen consumption should reveal evidence useful in predicting distributional patterns of closely related species.

The current investigation on the respiratory physiology of Nereis virens, $N$. succinea and $N$. diversicolor attempts to assess the effects of temperature and salinity changes on simultaneously measured ventilation and oxygen uptake and to relate the interspecific differences to the distributional patterns of these species.

\section{MATERIALS AND METHODS}

\section{Animals}

Experimental animals were collected during April and May, 1982 in Kysing Fjord, Denmark. The estuary's water temperature and salinity showed consider- 
able fluctuations due to solar radiation and tides ( 8 to $20{ }^{\circ} \mathrm{C} ; 5$ to $24 \% \mathrm{~S}$ ). The worms were collected from the following habitats: Nereis virens in the outer part of the estuary on a sandflat of low to medium organic content; $N$. succinea, in the lower intertidal zone of the outer part of the estuary in sandy mud with dense growth of Mytilus edulis; $N$. diversicolor, in silty sand at the high intertidal of the middle part of the estuary. The areas were subjected to variable periods of submergence.

Worms for both temperature and salinity experiments were allowed to acclimate to $20{ }^{\circ} \mathrm{C}$ and $19 \% \mathrm{~S}$ for at least $7 \mathrm{~d}$ in natural sediment. Before experiments, the experimental animals were transferred to Petri dishes, provided with polyethylene tubing for artificial burrows, and maintained for $2 \mathrm{~d}$, during which time they voided their guts.

\section{Measurements of ventilation and oxygen uptake}

The experiments were performed with worms inhabiting polyethylene tubes. To prevent errors due to microbial oxygen uptake, the tubes employed were cleaned before measurements (Kristensen, 1983).

Ventilation was determined with an electromagnetic flowmeter (Kristensen, 1981b, 1983) and measured as ventilation amplitude $\left(\dot{\mathrm{V}}_{\mathrm{w}}\right)$ computed as the mean flow rate during periods of active ventilation. The results are expressed as $\mathrm{ml} \mathrm{min} \mathrm{m}^{-1}$, standardized to a $0.5 \mathrm{~g}$ wet wt. individual, using the relationship reported by Kristensen (1981b).

Oxygen extraction during active periods was recorded continuously by a Radiometer $\mathrm{P}_{\mathrm{O}_{2}}$-electrode (Kristensen, 1983), and oxygen consumption $\left(\dot{V}_{\mathrm{O}_{2}}\right)$ was calculated as, $\dot{\mathrm{V}}_{\mathrm{O}_{2}}=\dot{\mathrm{V}}_{\mathrm{w}} \times$ Extr., expressed as $\mu \mathrm{g} \mathrm{O}_{2}$ $\mathrm{g}^{-1} \mathrm{~h}^{-1}$ standardized to a $0.5 \mathrm{~g}$ wet wt. individual.

\section{Effects of temperature changes}

In order to establish the effects of temperature changes on ventilation and oxygen consumption at full air saturation, the worms were exposed to temperatures from 5.5 to $37.5^{\circ} \mathrm{C}$. Measurements were made for 4 to 5 individuals of each species at temperature steps above acclimation level: 20.0, 25.0, 30.0, 35.0 and $37.5^{\circ} \mathrm{C} ; 4$ to 5 individuals of the same sizes were measured at temperature steps decreasing from acclimation temperature: 20.0, 16.0, 11.0 and $5.5^{\circ} \mathrm{C}$. After each temperature step the worms were allowed to acclimate for $24 \mathrm{~h}$ before monitoring in order to reduce the acute temperature responses commonly exhibited by marine invertebrates (Kinne, 1963, 1970; Prosser, 1973; Newell and Branch, 1980). Each individual was monitored for about $1 \mathrm{~h}$. A constant salinity of $19 \% \mathrm{~S}$ was maintained during experiments. The size ranges used were: $N$. virens, 0.5 to $1.9 \mathrm{~g} ; N$. succinea, 0.5 to $1.6 \mathrm{~g} ; \mathrm{N}$. diversicolor, 0.2 to $0.7 \mathrm{~g}$ wet wt.

\section{Effects of salinity changes}

To study the effects of decreasing salinity on ventilation and oxygen uptake at full air saturation, 4 individuals of each species were measured at stepwise, decreasing salinities from 24.0 to $1.7 \% \mathrm{~S}$. The salinities chosen were: $24.0,18.0,13.2,8.1$ and $1.7 \% \mathrm{~S}$. Before the start of experiments, the $19 \% \mathrm{~S}$ acclimated worms were exposed for $24 \mathrm{~h}$ to the initial salinity $(24 \% \mathrm{~S})$, chosen because this is the maximum value reported from the collection area (Muus, 1967). At each salinity, acclimation was allowed for the same time length before monitoring. The size ranges used were: $N$. virens, 0.7 to $2.0 \mathrm{~g} ; N$. succinea, 0.5 to $1.0 \mathrm{~g}$; and $N$. diversicolor, 0.3 to $0.5 \mathrm{~g}$ wet wt. Each individual was monitored for about $1 \mathrm{~h}$. Temperature was kept constant at $20^{\circ} \mathrm{C}$ during experiments.

\section{RESULTS}

\section{Effects of temperature changes}

Fig. 1 A illustrates the relationship between ventilation amplitude $\left(\dot{\mathrm{V}}_{\mathrm{w}}\right)$ and temperature in the range 5.5 to $37.5^{\circ} \mathrm{C}$ for the 3 nereids. For all 3 species, $\dot{V}_{w}$ increased directly with temperature reaching a well defined maximum level at 20 and $16^{\circ} \mathrm{C}$ for Nereis virens and $N$. diversicolor and at $25^{\circ} \mathrm{C}$ for $N$. succinea. The temperature coefficient $\left(Q_{10}\right)$ was very similar for the 3 species, 2.61 to 2.91 (Table 1). The worms maintained the $\dot{V}_{w}$ maximum for a further $10^{\circ} \mathrm{C}$ increase in temperature $\left(Q_{10}=1.00\right.$ to 1.06$)$, suggesting that the upper limits of ventilation capacity were reached. At temperatures above $30^{\circ} \mathrm{C}$, both $N$. virens and $N$. diversicolor ceased ventilation; possibly due to heat stress, but they survived $35^{\circ} \mathrm{C}$ for at least $24 \mathrm{~h}$. For $N$. succinea ventilation decreased at temperatures above $35^{\circ} \mathrm{C}$ (Fig. $1 \mathrm{~A}$ ), suggesting the onset of thermal stress. $\dot{\mathrm{V}}_{\mathrm{w}}$ for $N$. diversicolor was 2 to 3 times that of $N$. virens over the entire range of temperatures $(p<0.05)$. N. succinea ventilation was intermediate to that of the other 2 species below $20.0^{\circ} \mathrm{C}$, but above that temperature $\dot{V}_{w}$ for $N$. succinea exceeded that of $N$. diversicolor $(1.3$ to 1.6 times).

The duration of ventilation periods $\left(D_{v}\right)$ increased in all 3 species with temperature (Fig. 1B), but pattern and magnitude of the increase were different. $N$. diversicolor appeared to be quite unaffected by temperature 


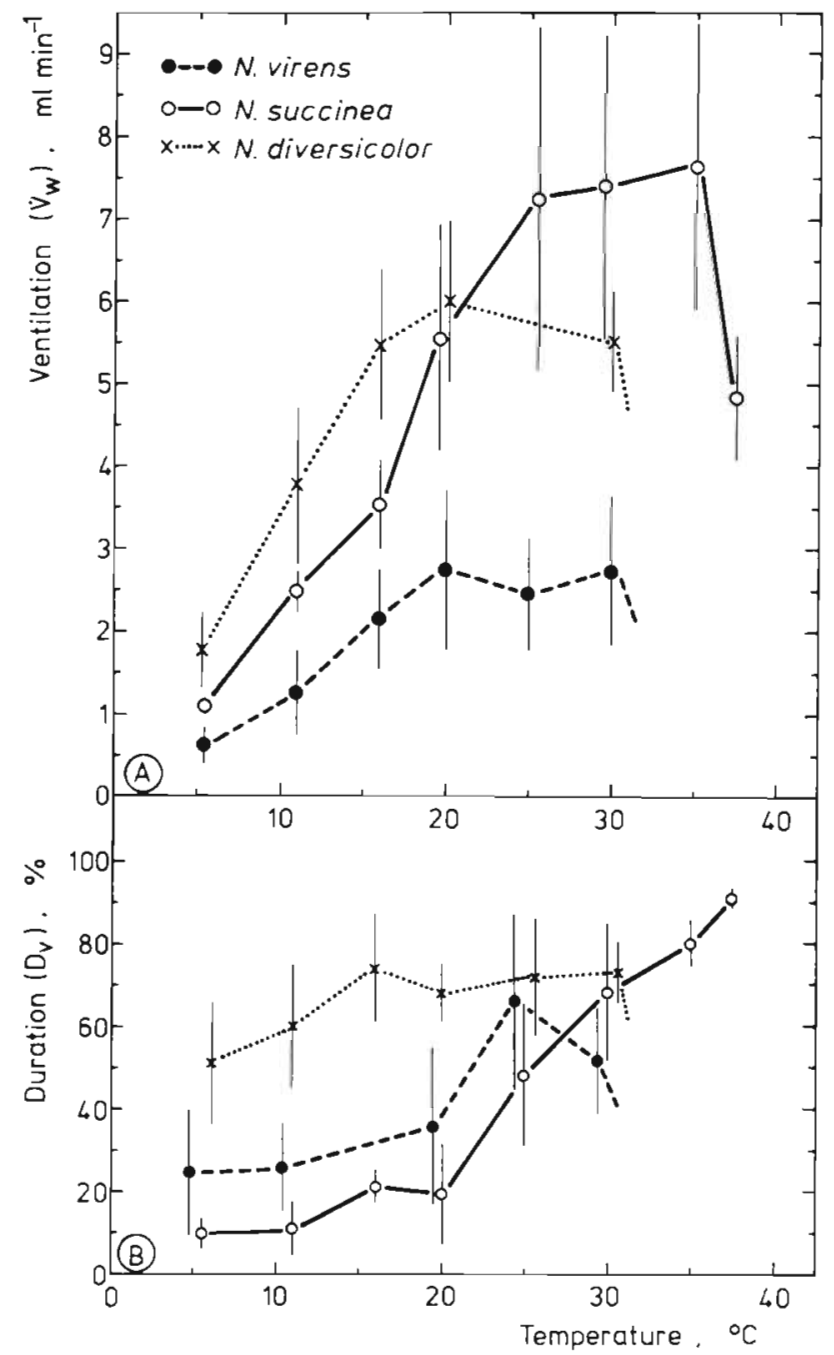

Fig. 1. Nereis virens, N. succinea, $N$. diversicolor. (A) Ventila-

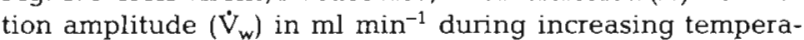
ture $\left(t^{\circ} \mathrm{C}\right)$ for $0.5 \mathrm{~g}$ wet wt. standard individuals. (B) Duration of ventilation in $\%$ of the total measured time $\left(D_{v}\right)$ during increasing temperature. Results given as mean \pm S. D. of ca. $1 \mathrm{~h}$ recordings of 4 to 5 individuals

Table 1. Nereis virens, $N$. succinea, $N$. diversicolor. $Q_{10}$ values of $\dot{V}_{w}, D_{v}$ and $\dot{V}_{O_{2}}$ in low and high temperature intervals

\begin{tabular}{|lcccc|}
\hline Species & $\Delta \mathrm{t}^{\circ} \mathrm{C}$ & $\dot{\mathrm{V}}_{\mathrm{w}}$ & $\begin{array}{c}\mathrm{Q}_{10} \\
\mathrm{D}_{\mathrm{v}}\end{array}$ & $\dot{\mathrm{V}}_{\mathrm{O}_{2}}$ \\
\hline N. virens & $5.5-20.0$ & 2.82 & 1.29 & 1.84 \\
N. succinea & $5.5-25.0$ & 2.61 & 1.57 & 1.64 \\
N. diversicolor & $5.5-16.0$ & 2.91 & 1.42 & 2.20 \\
& & & & \\
N. virens & $20.0-30.0$ & 1.00 & 1.43 & 1.47 \\
$N$. succinea & $25.0-35.0$ & 1.06 & 1.65 & 1.25 \\
$N$. diversicolor & $16.0-30.0$ & 1.01 & 0.99 & 1.80 \\
& & & & \\
5.5-20.0 ${ }^{\circ} \mathrm{C}$ & & & & \\
\hline
\end{tabular}

over the range measured, showing only a slight increase $\left(Q_{10}=1.13\right) ; N$. virens and $N$. succinea exhibited a similar response below $20.0^{\circ} \mathrm{C}\left(\mathrm{Q}_{10}=1.29\right.$ to 1.57) (Fig. 1B, Table 1). Above $20.0^{\circ} \mathrm{C}$, when the upper limit of $\dot{V}_{w}$ was reached, $D_{v}$ for these 2 species increased markedly, suggesting a compensatory response.

The influence of temperature change on the oxygen consumption $\left(\dot{\mathrm{V}}_{\mathrm{O}_{2}}\right)$ by Nereis spp. during ventilation periods is illustrated in Fig. 2. $\dot{\mathrm{V}}_{\mathrm{O}_{2}}$ increased with

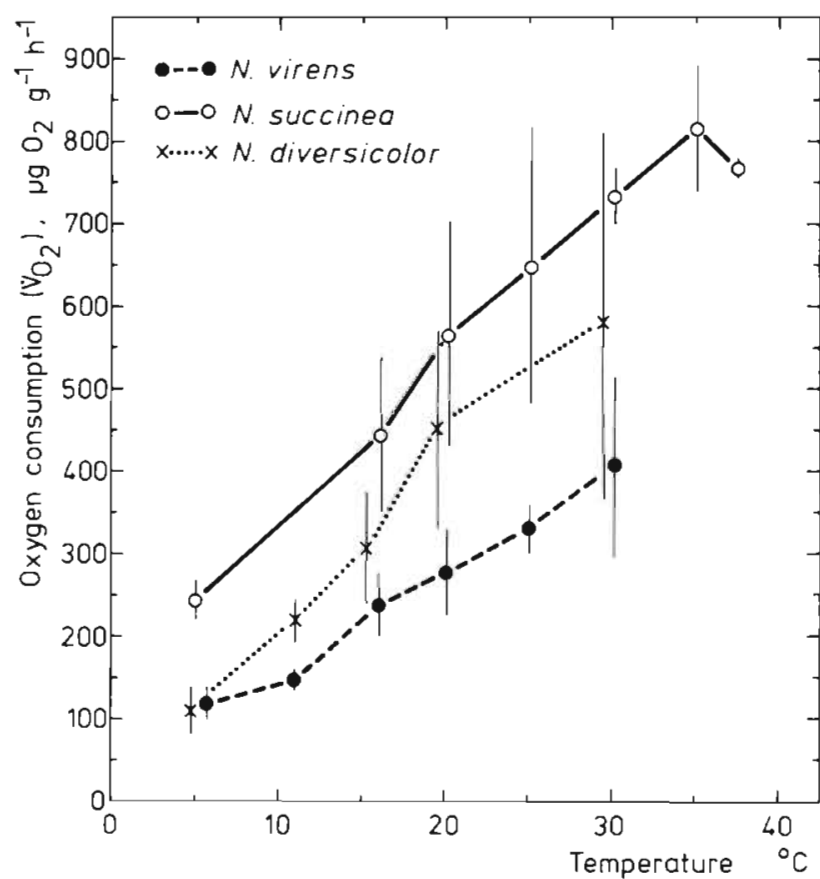

Fig. 2. Nereis virens, $N$. succinea, $N$. diversicolor. Oxygen uptake during active periods by $0.5 \mathrm{~g}$ wet wt. standard individuals during increasing temperature. Results given as mean \pm S.D. of ca. $1 \mathrm{~h}$ recordings of 4 to 5 individuals

temperature in all 3 species, exhibiting a steeper increase at temperatures below $20.0^{\circ} \mathrm{C}\left(Q_{10}=1.64\right.$ to $2.20)$ than above $\left(Q_{10}=1.25\right.$ to 1.80$)$. $\dot{V}_{\mathrm{O}_{2}}$ for $N$. virens and $N$. succinea was significantly different over the measured range of temperatures $(p<0.05)$, the latter species consuming twice that of the former. $\dot{\mathrm{V}}_{\mathrm{O}_{2}}$ of $N$. diversicolor generally was intermediate to the other species.

\section{Effects of salinity changes}

Fig. $3 \mathrm{~A}$ illustrates the effect of declining salinity on $\dot{V}_{w}$ of $0.5 \mathrm{~g}$ individuals of Nereis spp. All 3 species responded to low salinity conditions with a reduction in $\dot{\mathrm{V}}_{\mathrm{w}}$. For $\dot{N}$. virens, $\dot{\mathrm{V}}_{\mathrm{w}}$ decreased below $13.2 \% \mathrm{~S}$. At $3.1 \% \mathrm{~S}$ all individuals of $N$. virens died within $24 \mathrm{~h} . N$. succinea and $N$. diversicolor demonstrated similar pat- 


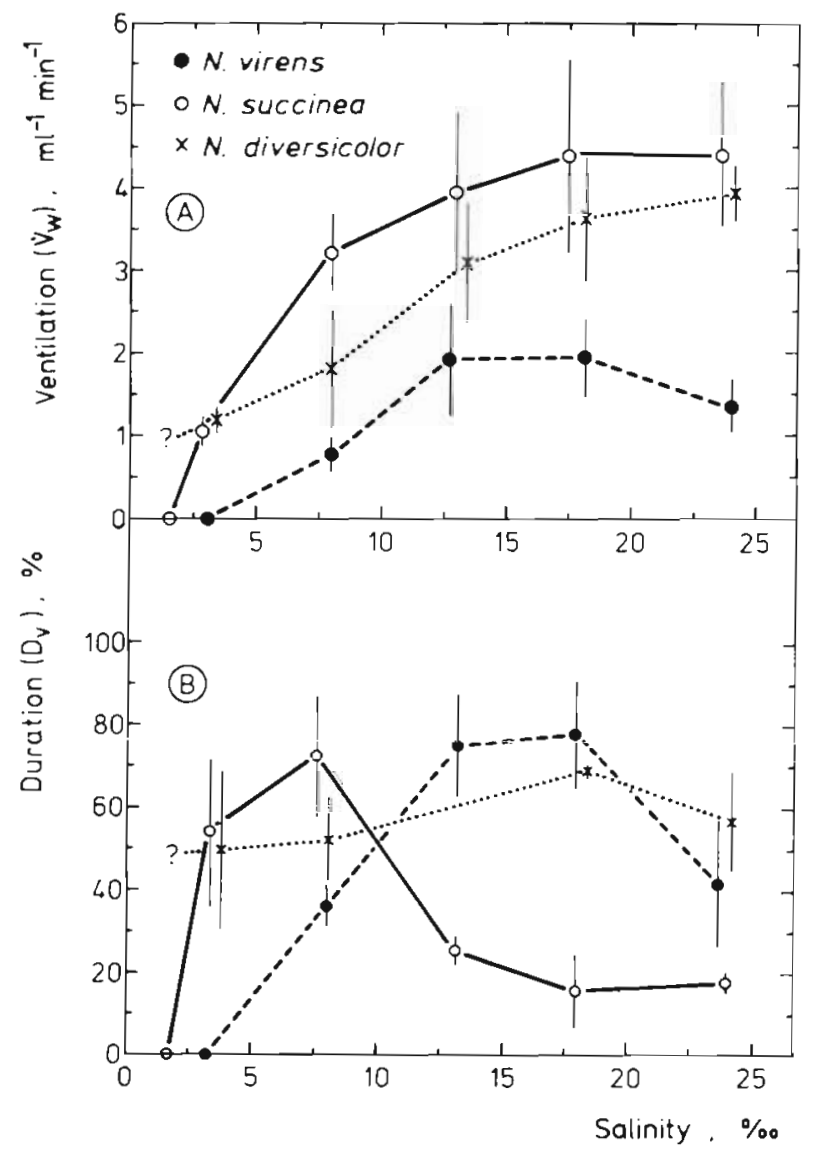

Fig. 3. Nereis virens, $N$. succinea and $N$. diversicolor. (A) Ventilation amplitude $\left(\dot{V}_{w}\right)$ in $\mathrm{ml} \mathrm{min}^{-1}$ during decreasing ambient salinity for $0.5 \mathrm{~g}$ wet wt. standard individuals. (B) Duration of ventilation in \% of the total measured time $\left(D_{v}\right)$ during decreasing salinity. Results given as mean \pm S.D. of ca. $1 \mathrm{~h}$ recordings of 4 individuals

terns of decrease in $\dot{\mathrm{V}}_{\mathrm{w}}$ during a salinity reduction from 24.0 to $8.1 \% \mathrm{~S}$. Below $8.1 \% \mathrm{~S}$ the former exhibited a swifter decrease in $\dot{V}_{w}$ than the latter, and at $1.7 \% \mathrm{~S}$ all $N$. succinea died within $24 \mathrm{~h}$. Due to failure in flowmeter equipment, no measurements were performed at $1.7 \% \mathrm{~S}$, but all $N$. diversicolor survived this salinity for more than $24 \mathrm{~h}$; by direct observation, ventilation activity could be detected but not quantified. $\dot{V}_{w}$ for $N$. succinea was 2 to 4 times that of $N$. virens at all salinities $(\mathrm{p}<0.05) . \dot{V}_{\mathrm{w}}$ of $N$. diversicolor was intermediate to the other species.

$D_{v}$ for Nereis diversicolor appeared to be quite unaffected by decreasing salinity, remaining fairly constant over the entire range $\left(D_{v}=50\right.$ to $\left.70 \%\right)$ (Fig. 3B). For $N$. succinea, no significant changes were observed in $D_{v}$ down to $13.2 \% \mathrm{~S}\left(D_{v}=15\right.$ to $\left.25 \%\right)$, but below that salinity $D_{v}$ showed a rapid increase, reaching $70 \%$ at $8.1 \%$ S. A similar increase was observed for $N$. virens from 24.0 to $18.0 \%$ S, suggesting a higher sensitivity to low salinity conditions for this species. For both $N$. virens and $N$. succinea, $D_{v}$ decreased at lower salinities, below 13.2 and $3.2 \%$ S, respectively.

A reduction in salinity from 24.0 to $3.1 \%$ S caused no significant changes in active $\dot{\mathrm{V}}_{\mathrm{O}_{2}}$ for $N$. succinea and $N$. diversicolor (Fig. 4); this contrasted the response in $\dot{V}_{w}$. The mean $\dot{\mathrm{V}}_{\mathrm{O}_{2}}$ of $N$. virens apparently increased about $100 \%$ from 18.0 to $8.1 \% \mathrm{~S}$, due to variability in the data this increase was not significant $(p>0.05)$.

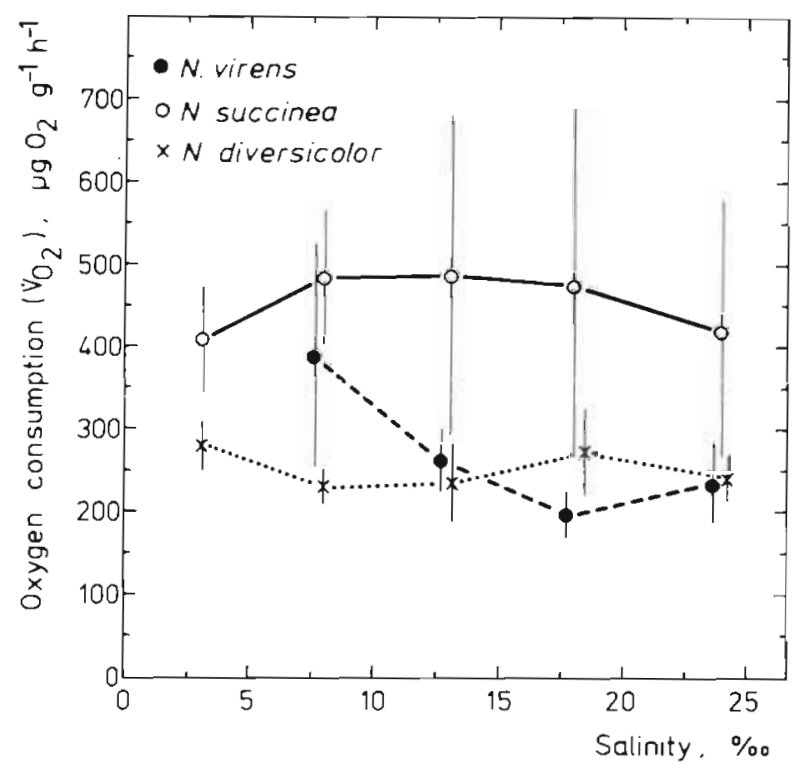

Fig. 4. Nereis virens, $N$. succinea and $N$. diversicolor. Oxygen uptake during active periods by $0.5 \mathrm{~g}$ wet wt. standard individuals during decreasing salinity. Results given as mean \pm S.D. of ca. $1 \mathrm{~h}$ recordings of 4 individuals

\section{Ventilation requirement}

The ratio $\mathrm{mi}$ water ventilated/ $\mu \mathrm{l}$ oxygen consumed $\left(\dot{\mathrm{V}}_{\mathrm{w}} / \dot{\mathrm{V}}_{\mathrm{O}_{2}}\right)$ (Jørgensen, 1952) is commonly used to estimate the concentration of available organic matter needed in order to meet the maintenance requirements of bivalve molluscs (for review see Newell and Branch, 1980). This index might also be used as a basis for comparison between organisms under different environmental conditions. For tube-dwelling polychaetes, the inverse ratio, $\mu \mathrm{l}$ oxygen consumed $/ \mathrm{ml}$ water ventilated $\left(\vec{V}_{\mathrm{O}_{2}} \sim_{\mathrm{w}}\right)$, 'ventilation requirement', appear more appropriate to use as an index for comparing effects of changing environmental conditions.

During changing temperatures, the ventilation requirement $\left(\dot{V}_{\mathrm{O}_{2}} / \dot{\mathrm{V}}_{\mathrm{w}}\right)$ for the 3 species of Nereis studied showed considerable interspecific differences (Fig. 5). For all 3, minimum ratios were observed over a 10 to $15^{\circ}$ range, i.e. between 5 and $15^{\circ} \mathrm{C}$ for $N$. diversicolor and between 20 and $35^{\circ} \mathrm{C}$ for $N$. succined, suggesting this range as the optimum at the present acclimation temperature $\left(20^{\circ} \mathrm{C}\right) . \dot{\mathrm{V}}_{\mathrm{O}_{2}} / \dot{\mathrm{V}}_{\mathrm{w}}$ was lowest for 


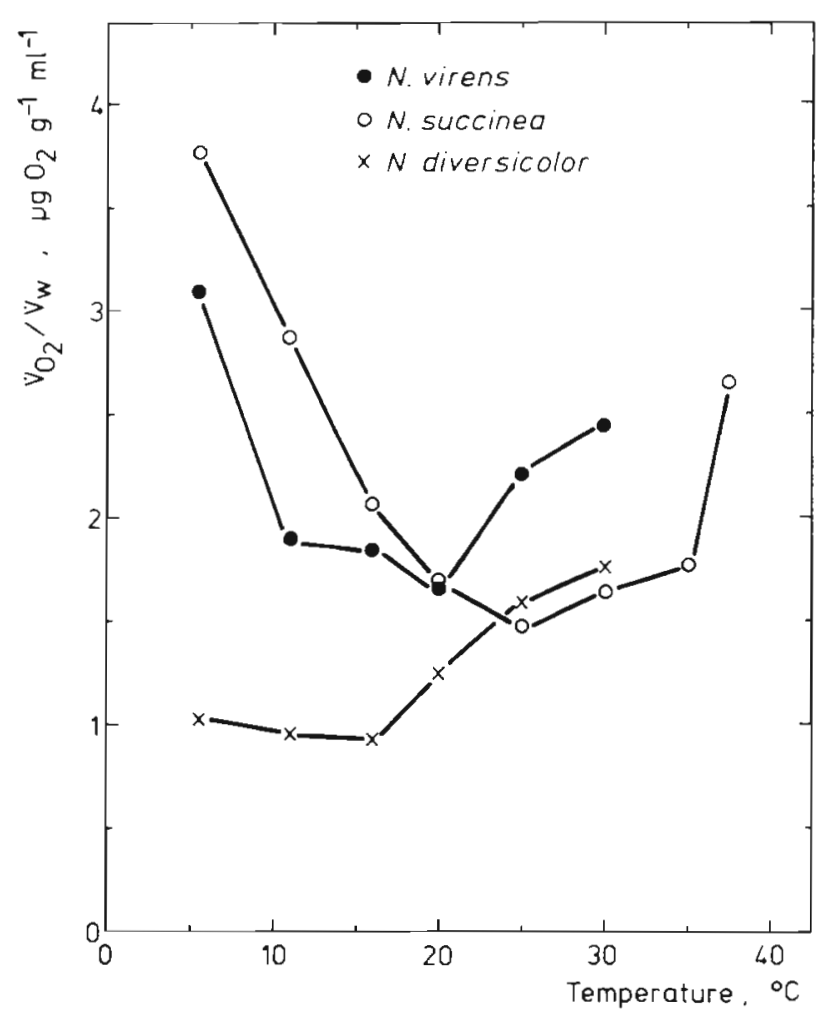

Fig. 5. Nereis virens, $N$. succinea, $N$. diversicolor. Ventilation requirement $\left(\hat{\mathrm{V}}_{\mathrm{O}_{2}} / \dot{\mathrm{V}}_{\mathrm{w}}\right)$ during changing temperatures

$N$. diversicolor at temperatures below the acclimation level, $N$. virens reached minimum values below and at the acclimation temperature, and $N$. succinea showed the lowest figures above that temperature.

Decreasing salinities from 24.0 to $13.2 \%$ S affected the ventilation requirement for the 3 species only slightly. $N$. virens showed a drastic increase from 13.2 to $8.1 \% \mathrm{~S}$. A similar increase appeared for $N$. succinea below $8.1 \% \mathrm{~S}$ (Fig. 6). For $N$. diversicolor no such sharp increase was observed; the ratio $\dot{V}_{O_{2}} / \dot{V}_{w}$ only showed a gradually increase during lowered salinity, indicating no clearcut lower limit in contrast to the other species.

\section{DISCUSSION}

The great majority of data on the effects of changing environmental conditions on polychaete oxygen uptake were recorded without independent consideration of motor and ventilatory activity (Mangum, 1972; Ivleva, 1973; Young and Anderson, 1974; Mangum, 1978; Beis et al., 1980; Ferraris and Trivelpiece, 1980; McMahon and Russel-Hunter, 1980). The present study revealed that ventilation and oxygen uptake of Nereis spp. increased markedly with temperature from $5.5^{\circ} \mathrm{C}$ to 16 to $25^{\circ} \mathrm{C}$ (Figs $1 \mathrm{~A} ; 2$ ). The $\mathrm{Q}_{10}$ values in this

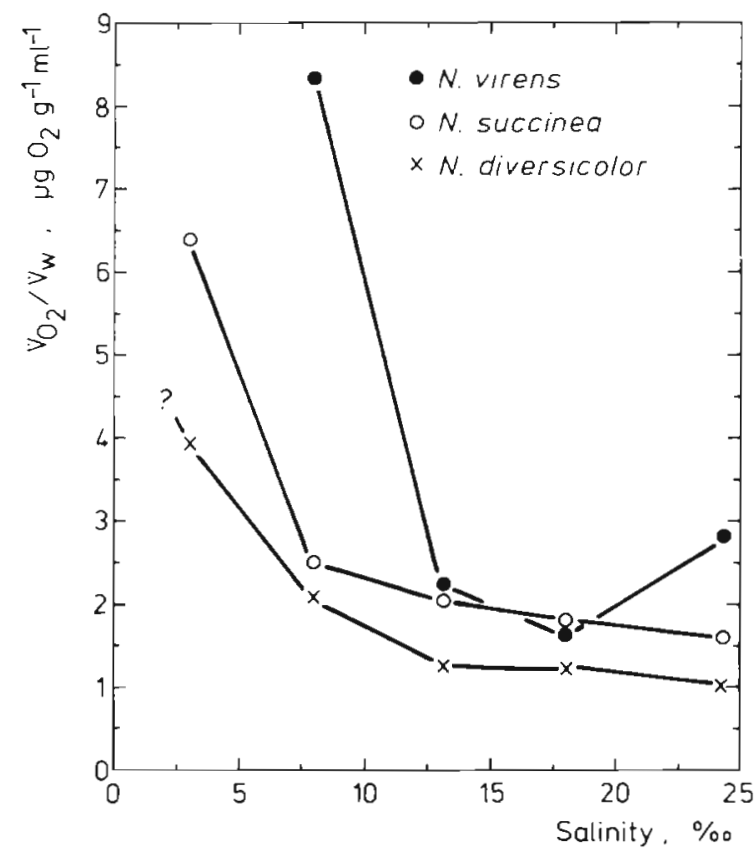

Fig. 6. Nereis virens, $N$. succinea, $N$. diversicolor. Ventilation requirement $\left(\dot{\mathrm{V}}_{\mathrm{O}_{2}} / \dot{\mathrm{V}}_{\mathrm{w}}\right)$ during decreasing salinity

temperature range were higher for $\dot{V}_{w}$ (2.61 to 2.91) than for $\dot{\mathrm{O}}_{\mathrm{O}_{2}}(1.64$ to 2.20$)$ and $\mathrm{D}_{\mathrm{v}}(1.29$ to 1.57 ) (Table 1$)$. Previous reports on ventilation of other polychaete species revealed $Q_{10}$ values somewhat lower than for the $V_{w}$ obtained here, i.e. Arenicola marina, $Q_{10}=2.14$ (6 to $20^{\circ} \mathrm{C}$ ) (Baumfalk, 1979) or $1.17\left(12.25\right.$ to $14.45^{\circ} \mathrm{C}$ ) (Seymour, 1972); and for Diopatra cuprea, $\mathrm{Q}_{10}=1.60$ to 1.88 (12.5 to $27.5^{\circ} \mathrm{C}$ ) (Mangum and Sassaman, 1969). The values of Seymour and of Mangum and Sassaman were not based on $\dot{\mathrm{V}}_{\mathrm{w}}$, but ventilation frequency, which is comparable to $D_{v}$. The $Q_{10}$ for $\dot{V}_{\mathrm{O}_{2}}$ reported here agree with earlier studies on polychaetes, i.e. for Diopatra cuprea, $\mathrm{Q}_{10}=1.77\left(17.5\right.$ to $27.5^{\circ} \mathrm{C}$ ) (Mangum and Sassaman, 1969); Glycera dibranchiata, $\mathrm{Q}_{10}=1.91$ to 2.30 (Coyer and Mangum, 1973). Despite constancy in $\dot{\mathrm{V}}_{\mathrm{w}}$ at temperatures from 16 to $25^{\circ} \mathrm{C}$ to 30 to $35^{\circ} \mathrm{C}$ $\left(Q_{10}=1.00\right.$ to 1.06$), \quad \dot{V}_{\mathrm{O}_{2}}$ continued to increase $\left(Q_{10}=1.25\right.$ to 1.80$)$. With a further increase in temperature, heat coma sets in at the critical temperature maximum (Kinne, 1971), between 30 and $35^{\circ} \mathrm{C}$ for $N$. virens and $N$. diversicolor, and above $37.5^{\circ} \mathrm{C}$ for $N$. succinea. The cessation of ventilation by Nereis at high temperatures, but below the lethal limit, might be due to an internal mechanism that reduces or stops ventilation activity when the surface water is in some way noxious for the animals (Wells and Albrecht, 1951). The critical temperature maxima, reported here for nereids previously acclimated to $20^{\circ} \mathrm{C}$, are probably not fixed for these species, since thermal tolerance for marine invertebrates will tend to show translation of temperature curves following acclimation temperature 
(Newell and Bayne, 1973; Mangum, 1978; Newell and Branch, 1980).

The ventilation requirement $\left(\dot{\mathrm{V}}_{\mathrm{O}_{2}} / \dot{\mathrm{V}}_{\mathrm{w}}\right)$ changed with altered temperatures, and reached minimum values at species specific temperatures (Fig. 5). These changes might be due to the fact that the ventilation requirement includes a variety of energy consuming processes other than muscular activity itself (Newell and Kofoed, 1977). The temperature range of minimum ventilation requirement, where maximal ventilation efficiency was obtained, is assumed to be the optimum temperatures for these nereids. The interspecific differences in ventilation requirement suggested adaptation to low ambient temperatures in Nereis diversicolor and $N$. virens, and adaptation to higher temperatures in $N$. succinea. These adjustments may be considered genetic adaptations of metabolic rates, since the 3 species were preacclimated to the same temperature for a period of at least $9 \mathrm{~d}$, as reported for the polychaetes Clymenella spp. and Diopatra sp. (Mangum, 1963). Smith (1963) reported that $N$. succinea in the early 1950 's was extending its range northward in Europe. In Denmark the first adult specimens of this species were collected in 1953 (Rasmussen, 1973). These points of evidence suggest that, genetically, N. succinea is a warm-water species.

Nereis spp. respond to lowered salinities with a decreased $\dot{V}_{w}$, but not with an altered $\dot{V}_{\mathrm{O}_{2}}$ (Figs. $3 \mathrm{~A}_{;}$4). Several reports on ventilatory response to lowered salinities in marine invertebrates have revealed different results. Commonly crustaceans increase ventilation and muscular activity at low salinities (Taylor, 1977; Taylor et al., 1977; Dyer and Uglow, 1980). This is believed primarily to be the result of an increased locomotor activity associated with an escape reaction from water of unfavourable salinity (Taylor, 1977). For marine bivalves (Theede, 1963) and polychaetes (Wells and Ledingham, 1940; Shumway and Davenport, 1977) any marked decrease of salinity in the external medium result in a slowing down or inhibition of ventilation. Decreasing salinity is known to produce a swelling of the body of polychaetes, due to osmotic influx of water through the soft body walls (Sayles, 1935; Jørgensen and Dales, 1957; Oglesby, 1978). Beadle (1931) reported that the weight of Perinereis cultrifera and Nereis diversicolor rose after transfer to low salinity, and after several hours volume regulation, they both appeared very expanded and especially the former was capable of only very slight movements. This might inhibit peristaltic body movements, which occur during ventilation and explain the gradual decrease in $\dot{V}_{w}$ at decreasing salinities found presently for the 3 species of Nereis.

Ventilation requirement, especially of Nereis virens and $N$. succinea, showed a dramatic increase (300 to
$400 \%$ ) at salinities below 10 to $15 \%$ S (Fig. 6). The least euryhaline $N$. virens shows a much greater body swelling at low salinities than does the more euryhaline $N$. diversicolor (Beadle, 1931; Oglesby, 1978). This is in accord with, and might be responsible for, the greater increase in ventilation requirement observed for $N$. virens and $N$. succinea at low salinities than for $N$. diversicolor. Several reports reveal that the onset of hyperosmotic and hyperionic regulation of Nereis spp. occurs at salinities below 10 to $12 \% \mathrm{~S}$ (Oglesby et al., 1982; Quinn and Bashor, 1982), but the increased ventilation requirement cannot solely be due to increased demands for active ion transport. Potts (1954) showed that the energetic cost of ionic and osmotic regulation is low, accounting for only a small part of the observed oxygen consumption in marine invertebrates.

The interspecific differences shown here in ventilation requirement at different temperatures and salinities provides some evidence for explaining the distributional patterns of nereids in estuaries. Due primarily to its weak tolerance of low salinities, Nereis virens is never found in areas of low and fluctuating salinity, but always outside and in the mouth of estuaries (Muus, 1967; Rasmussen, 1973; Kristensen, 1981a). Both $N$. succinea and $N$. diversicolor can live at low salinities; the latter can even endure nearly freshwater conditions. However, $N$. succinea are never found in the upper intertidal and inner low salinity areas of estuaries (Muus, 1967; Kristensen, 1981a); these areas are always occupied by $N$. diversicolor. This might be due to the different thermal tolerances of these species. Possibly, the warm-water species $N$. succinea cannot survive the heavy ice-cover and low temperatures that develop during winter in the upper intertidal and inner parts of Danish estuaries. Of course, tolerance limits of temperature and salinity cannot explain fully the distributional patterns of these nereids, since a high degree of interspecific competition apparently exists among these species (Kristensen, 1981a).

Acknowledgements. My gratitude is due to Dr. J. P. Lomholt, Dr. F. C. Dobbs, Dr. L. M. Cammen and Professor K. Johansen for critically reading and for valuable help in the preparation of the English manuscript. This research was supported by Grant no. 1979-22/523-42 from the University of Aarhus, Denmark.

\section{LITERATURE CITED}

Baumfalk, Y. A. (1979). On the pumping activity of Arenicola marina. Neth. J. Sea Res. 13:422-427

Beadle, L. C. (1931). The effect of salinity changes on the water content and respiration of marine invertebrates. $\mathrm{J}$. exp. Biol. 8: 211-227

Beis, I., Manousis, A., Barrett, J. (1980). Studies on the respiration of the polychaete Ophelia bicornis. Comp. Biochem. Physiol, 67 A: 303-305 
Coyer, P. E., Mangum, C. P. (1973). Effect of temperature on active and resting metabolism in polychaetes. In: Wieser, W. (ed.) Effects of temperature on ectothermic organisms. Springer-Verlag, Berlin-Heidelberg-New York, p. $173-180$

Dyer, M. F., Uglow, R. F. (1980). Cardiac and ventilatory changes associated with altered salinity in Crangon crangon (L.). Ophelia 19: 117-125

Ferraris, J. D., Trivelpiece, W. (1980). The effect of abnubt temperature and salinity change on oxygen uptake in two coral reef polychaetes. Am. Zool. 20: 731

Halcrow, K., Boyd, C. M. (1967). The oxygen consumption and swimming activity of the amphipod Gammarus oceanicus at different temperatures. Comp. Biochem. Physiol. 23: 233-242

Ivleva, I. V. (1973). Quantitative correlation of temperature and respiratory rate in poikilothermic animals. Pol. Arch. Hydrobiol. 20: 283-300

Jørgensen, C. B. (1952). On the relationship between water transport and food requirements in some marine filterfeeding invertebrates. Biol. Bull. mar. biol. Lab., Woods Hole 103: 356-363

Jørgensen, C. B., Dales, R. P. (1957). The regulation of volume and osmotic regulation in some nereid polychaetes. Physiologia comp. Oecol. 4: 357-374

Kinne, O. (1963). The effects of temperature and salinity on marine and brackish water animals. I. Temperature. Oceanogr. Mar. Biol. A. Rev. 1: 301-340

Kinne, O. (1970). Temperature: invertebrates. In: Kinne, O. (ed.) Marine ecology, Vol. I, Cultivation, Part 1. Wiley, London, p. 407-514

Kinne, O. (1971). Salinity: invertebrates. In: Kinne, O. (ed.) Marine ecology, Vol. I, Cultivation, Part 2. Wiley, London, p. 821-995

Kristensen, E. (1981a). Økologiske studier over tre Nereisarter i Kysing Fjord og Vellerup Vig. M.S. thesis, University of Aarhus, Aarhus

Kristensen, E. (1981b). Direct measurements of ventilation and oxygen uptake in three species of tubicolous polychaetes (Nereis spp.). J. Comp. Physiol. 145: 45-50

Kristensen, E. (1983). Ventilation and oxygen uptake by three species of Nereis (Annelida: Polychaeta). I. Effects of hypoxia. Mar. Ecol. Prog. Ser. 12: 289-297

Mangum, C. P. (1963). Studies on speciation in maldanid polychaetes of the North American Atlantic Coast. III. Intraspecific and interspecific divergence in oxygen consumption. Comp. Biochem. Physiol. 10: 335-349

Mangum, C. P. (1972). Temperature sensitivity of metabolism in offshore and intertidal onuphid polychaetes. Mar. Biol. 17: $108-114$

Mangum, C. P. (1978). Temperature adaptation. In: Mill, P. J. (ed.) Physiology of annelids. Academic Press, LondonNew York-San Francisco, p. 447-478

Mangum, C. P., Sassaman, C. (1969). Temperature sensitivity of active and resting metabolism in a polychaetous annelid. Comp. Biochem. Physiol. 30: 111-116.

McLusky, D. S. (1973). The effect of temperature on the oxygen consumption and filtration rate of Chlampys (Aequipecten) opercularis (L.) (Bivalvia). Ophelia 10: 141-154

McMahon, R. F., Russell-Hunter, W. D. (1980). Respiration in the polychaete worm Magelona: responses to temperature, hypoxia and tentacle ablation. Biol. Bull. mar. biol. Lab., Woods Hole 159: 451

Muus, B. J. (1967). The fauna of Danish estuaries and lagoons. Distribution and ecology of dominating species in the shallow reaches of the mesohaline zone. Meddr Danm. Fisk.-og Havunders. ny ser. 5: 1-316

Newell, R. C., Bayne, B. L. (1973). A review on temperature and metabolic acclimation in intertidal marine invertebrates. Neth. J. Sea Res. 7: 421-433

Newell, R. C., Branch, G. M. (1980). The influence of temperature on the maintenance of metabolic energy balance in marine invertebrates. Adv. mar. Biol. 17: 329-396

Newell, R. C., Kofoed, L. H. (1977). The energetics of suspension-feeding in the gastropod Crepidula fornicata L. J. mar. biol. A.ss. U.K. 57: 161-180

Oglesby, L. C. (1978). Salt and water balance. In: Mill, P. J. (ed.) Physiology of annelids. Academic Press, London, p. $555-658$

Oglesby, L. C. Mangum, C. P., Heacox, A. E., Ready, N. E. (1982). Salt and water balance in the polychaete Nereis virens. Comp. Biochem. Physiol. 73 A: 15-19

Potts, W. T. W. (1954). The energetics of osmotic regulation in brackish- and freshwater animals. J. exp. Biol. 17: $618-630$

Prosser, C. L. (1973). Comparative animal physiology, Vol. I, Environmental physiology. W. B. Saunders Company, Philadelphia

Quinn, R. H., Bashor, D. P. (1982). Regulation of coelomic chloride and osmolarity in Nereis virens in response to low salinities. Comp. Biochem. Physiol. 72 A: 263-265

Rasmussen, E. (1973). Systematics and ecology of the Isefjord marine fauna (Denmark). Ophelia 11: 1-507

Remane, A., Schlieper, C. (1971). Biology of brackish water. Wiley, New York

Sayles, L. P. (1935). The effects of salinity changes on body weight and survival of Nereis virens. Biol. Bull. mar. biol. Lab., Woods Hole 69: 233-244

Seymour, M. K. (1972). Effects of temperature change on irrigation rate in Arenicola marina (L.). Comp. Biochem. Physiol, 43A: 553-564

Shumway, S. E., Davenport, J. (1977). Some aspects of the physiology of Arenicola marina (Polychaeta) exposed to fluctuating salinities. J. mar, biol. Ass. U.K. 57: 907-924

Smith, R. I. (1963). On the occurence of Nereis (Neanthes) succinea at the Kristineberg Zoological Station, Sweden, and its recent northward spread. Ark. Zool. 15: 437-441

Taylor, A. C. (1977). The respiratory responses of Carcinus maenas (L.) to changes in environmental salinity. J. exp. mar. Biol. Ecol. 29: 197-210

Taylor, E. W., Butler, P. J., Al-Wassia, A. (1977). The effect of a decrease in salinity on respiration osmoregulation and activity in the shore crab, Carcinus maenas (L.) at different acclimation temperatures. J. Comp. Physiol. 119: 155-170

Theede, H. (1963). Experimentelle Untersuchungen über die Filtrationsleistung der Miesmuschel Mytilus edulis L. Kieler Meeresforsch. 19: 20-41

Wells, G. P., Albrecht, E. B. (1951). The integration of activity cycles in the behaviour of Arenicola marina L. J. exp. Biol. 28: $41-50$

Wells, G. P., Ledingham, I. C. (1940). Physiological effects of a hypertonic environment. I. The action of hypertonic salines on isolated rhythmic preparations from polychaete worms (Arenicola marina, Nereis diversicolor, Perinereis cultrifera). J. exp. Biol. 17: 337-352

Widdows, J. (1973). The effects of temperature on the metabolism and activity of Mytilus edulis. Neth. J. Sea Res. 7: 387-398

Young, L., Anderson, J. W. (1974). Influence of salinity and temperature on the $\mathrm{O}_{2}$ consumption of Neanthes arenaceodentata Moore. Am. Zool. 14: 1260 